\title{
Undemocratic Liberalism, Liberal Imperialism and the Rise of Populism
}

Liberalism vs Democracy

Rein Müllerson

\author{
Rein Müllerson \\ l'Institut de Droit International (IDI), Geneva, Switzerland \\ Member and former President; \\ Tallinn University \\ Professor Emeritus \\ ScopusAuthorID: 8550150900 \\ E-mail: rein1@live.co.uk \\ Address: C/o IHEID, Chemin Eugène-Rigot 2, Case postale 1672, CH-1211 Genève 21, Switzerland \\ DOI: $10.31278 / 1810-6374-2020-18-2-66-89$
}

\begin{abstract}
The roots of the currently intensifying conflict in Western societies between the cosmopolitan elites and the masses voting for populist parties lie in the inherent dialectical contradiction between democracy and liberalism exposed and exacerbated by the negative aspects of hyper-globalization. The liberal West, infected by the Fukuyamian germ, tried to make the whole world uniform by using policies of liberal imperialism. Liberalism may indeed survive, and even flourish, in a borderless world. However, contemporary democracy, being tied by the umbilical cord to the rise of nation-states, can hardly survive without strong sovereign states. Instead of pouring oil on the fire of the relentless struggle between self-declared progressivists and populists and looking for dragons (or bears) to slay abroad, Western politicians and mainstream media should resort to the art
\end{abstract}


of compromise in dealing with their political opponents at home and accept that in international relations balance of power is even more important than separation of powers in domestic politics.

Keywords: democracy, liberalism, liberal imperialism, populism, nationalism, nation-states

fter Fareed Zakaria published, more than twenty years ago,
an article on 'illiberal democracy' (Zakaria, 1997), the term
has firmly anchored in both academic and political discourse. Agreeing with Zakaria that there are democracies where liberal values are not in high esteem, I wondered whether the reverse could also be true. Can there exist political regimes that can be defined as liberal but undemocratic? Of course, there have been authoritarian regimes that have been economically liberal, but socially conservative and politically oppressive, like Chile under General Pinochet or South Korea under the military rulers. However, in Western democracies two spheres of liberalism-economic and socio-political-have usually coexisted as two sides of the same coin. Therefore, in my analysis below I will concentrate on liberal democracies where these two aspects of liberalism have for years coexisted more or less peacefully.

Today we can see more clearly-than just a decade or two ago-that there are indeed political regimes that can be defined as 'liberal' with respect to both aspects indicated above, but which have a serious deficit of democracy. Whereas in illiberal democracies it is democracy that trumps liberalism, under undemocratic liberalism it is liberalism that has the upper hand and puts constraints on democracy. Undemocratic liberalism is a political regime where only the first element of the famous triptych "the government of the people, by the people and for the people" works, that is, where participation of the people in governance is both formal and ineffective and where governance is exercised not in the interest of the majority. As I will try to show below, populism is a reaction to the development and spread of such regimes. It is not to say that this is the only cause of the current rise of populism 
or that liberalism trumping democracy can be cured by populist remedies. However, there is a certain causal link between populism and the deficit of democracy in Western liberal societies. If we leave aside societies where there is neither democracy nor liberalism, like Saudi Arabia or North Korea, and look closely at societies where these phenomena have existed for some time, we will see that many, if not most, Western societies have been infested with the germ of 'undemocratic liberalism.'

\section{GLOBALIZATION AND REVOLUTIONARY SITUATIONS}

The current wave of globalization, which in the 1990s was welcomed not only as a conditio sine qua non for the worldwide economic growth, but also as a vehicle for spreading the ideas and practices of liberal democracy, soon revealed its less attractive aspects. The current rise of populism is, to a great extent, conditioned by those negative effects of globalization that the French call 'la mondialisation malheureuse' (unfortunate globalization). In contrast to the recent past, today's populism is mostly a Western phenomenon, although there have been and still are populist leaders in the non-Western world as well.

Besides globalization and processes related to it, we can currently observe two interconnected revolutionary situations-geopolitical and socio-political. By definition, a revolutionary situation puts strains on all kinds of normative systems, including law and morality, since, being a normative phenomenon, it functions well in circumstances that could be called normal. During revolutionary periods (like in France at the end of the 18th century, or in Russia at the beginning of the 20th century when normalcy was an exception and expediency ruled), law breaks down and even morality loses its guiding force. In this respect, international society is not an exception.

The first revolutionary transformation-geopolitical—started at the end of the 1980s with the collapse of the rather stable bipolar international system, which was going through a unipolar moment in the 1990s and is now moving towards some kind of multipolarity. The unipolar moment of the 1990s was short not only due to a series of fundamental mistakes committed by all consecutive American 
administrations (the wars in Afghanistan and Iraq, alienation of Russia, the encouragement and support of the Arab Spring, etc.), but also, and most importantly, because never before in history had one "hyperpower," to use the expression of former French Foreign Minister Hubert Védrine, dominated the whole world. Even the Mongol Empire of Genghis Khan and the British Empire controlled only parts of the world. The 1990s were a period of historical aberration in international and domestic affairs of some societies, and especially of Russia, where that period can be compared with the so-called Time of Troubles of 1598-1613. Naturally, in international relations attempts were soon made to counterbalance the dominant center. It is difficult to expect international law to function 'normally' again until the "revolutionary dust" settles down, one way or another, and new 'normalcy' emerges (or the old returns, although this is a less plausible scenario).

The second revolutionary situation, related to the first one, is the crisis of liberal democracy that was meant to triumph after the failure of its main ideological rival-communism. In the 1990s, many of those who publicly disagreed with Francis Fukuyama's "end of history" theory or disparaged some of his premises and conclusions, were nevertheless crypto Fukuyamians. The promotion of ideas and practices of liberal democracy all over the world was one of the important components of foreign policy of practically all Western states, and also of international organizations, including the UN. However, the disappearance of the principal enemy revealed, although not immediately, contradictions between liberalism and democracy.

\section{DIALECTICAL CONTRADICTIONS OF DEMOCRACY WITH RELATED PHENOMENA}

Years ago, the Curatorium of the Hague Academy of International Law asked me to give a course on the promotion of democracy, with special emphasis on Central Asia. This was the region where I had worked as a UN Regional Advisor, trying, among other tasks, to promote democracy and human rights. I gave the course in 2008, and analyzed, inter alia, dialectical contradictions that democracy has with two related phenomena-nationalism and liberalism. These three notions 
have a kind of frère/ennemi relationships, that is, they are mutually supportive in certain contexts, while limiting or even undermining one another in other circumstances. However, twelve years ago these contradictions were not as intensive as today, while populism was still a marginal phenomenon. Those, who were accused of being populists, were primarily leftist leaders of Third-World countries, like Hugo Chavez of Venezuela or Rafael Correa of Ecuador.

The germ of the crisis of liberal democracy is, in my opinion, inherent in the dialectical controversy between democracy and liberalism. Aristoteles is supposed to have said: "Man is by nature a social animal; an individual who is unsocial naturally and not accidentally is either beneath our notice or more than human. Society is something that precedes the individual. Anyone who either cannot lead the common life or is so self-sufficient as not to need to, and therefore does not partake of society, is either a beast or a god." Democracy, be it in Ancient Greece or in today's "post-modern" West, accentuates the collectivistic or societal side of humanity, while current liberalism emphasizes and exaggerates its individualistic characteristics, aiming at the liberation of the individual from various social bonds, some of which have, indeed, been quite oppressive. However, in such a situation, many of us, liberated from responsibilities vis-à-vis others (families, parents, children, neighbors, etc.) and society as a whole, start considering themselves to be gods while acting as beasts. If excesses of collectivism tend to lead to totalitarianism, excesses of liberalism, tearing apart societal bonds, create conditions for might makes right.

Although these two phenomena-liberalism and democracy-have mostly been supportive of each other, there has always been a need for constant balancing between them. Too much democracy has often meant less liberalism and vice versa. Most Western, especially Western European, societies have until recently managed this controversy relatively well. In some, democracy has had the upper hand (for example, in Scandinavian social democracies), while in others liberalism has prevailed, but there have not so far been open conflicts between these two phenomena. However, due, first, to the rapid globalization of the world and later also to the changing balance of power in the international 
system, this controversial friend-enemy relationship between democracy and liberalism has become less friendly and more inimical.

In the globalized world these are not only authoritarian regimes that constitute a threat to democracy in their countries. The spread and liberalization of global, particularly financial, markets are also curbing democracy. Increasing the overall GDP of many countries, unbridled liberal markets make a few extremely rich while the majority of people are left behind. The wealth gaps are increasing practically in all countries. If in autocracies people are powerless vis-à-vis their rulers, in the globalized world people, as well as governments elected by them, are powerless vis-à-vis global markets, even if they live in so-called liberal democracies. This is how economic liberalism is undermining democracy. At the same time, the rise in importance of individual rights and rights of a multitude of minorities, who aggressively promote their-often newly-found-identities, are undermining social cohesion and common societal values. This is how social liberalism destabilizes democracy. As it usually happens, rare early warnings remained unheard of. For example, almost a quarter of a century ago, Richard Rorty published a small book, Achieving Our Country, where he wrote that the American liberal left, concentrating on the rights of ethnic, racial, religious, cultural, and sexual minorities, had neglected the widening gap between the rich and the poor. At some point, Rorty warned, "something will crack. The non-suburban electorate will decide that the system has failed and start looking around for a strongman to vote for-someone willing to assure them that, once he is elected, the smug bureaucrats, tricky lawyers, overpaid bond salesmen, and postmodern professors will no longer be calling the shots" (Rorty, 1997, p.90). Sounds eerily familiar and up to date, does it not? Rorty considered himself to belong to the category of the liberal left, although as one of the brightest representatives of American pragmatism he could not be branded a post-modern professor. And contrary to many, if not the most, he did not ridicule, deplore or detest those who were different, but as Baruch Spinoza had advised, tried to understand them and their concerns.

The current conflict between liberalism and democracy is reflected, inter alia, in the fact that liberal elites in most Western countries 
have started labeling those democrats whose policies and ideas (or personalities) they do not like as populists (let us recall that Ralf Dahrendorf has noted that, "one man's populism is another's democracy, and vice versa," although he has also qualified this statement by claiming that "while populism is simple, democracy is complicated" (Dahrendorf, 2003, p.25). At the same time, democrats (or populists) consider liberals to be arrogant elitists who have become alienated from the people, from their needs and ways of thinking, believing them to be losers and ill-informed (let's recall Hillary Clinton's characterization, though later hypocritically retracted, of Donald Trump's supporters as "racist, sexist, homophobic deplorables"). There is quite a lot of truth in the accusations of both sides-from the side of self-declared progressists as well as from the side of those whom their detractors classify as populists. Today we see that dialectical contradictions between liberalism and democracy, if not carefully and wisely handled, start tearing some hitherto stable societies apart.

\section{PROBLEMS OF ADAPTABILITY TO RAPID CHANGES}

It is not only interesting, but also enlightening to recall that the current crisis of liberal democracy has parallels with problems and debates that took place, mostly in the United States, a century ago. French philosopher Barbara Stiegler, in her recent excellent study with an emblematic title, Il faut s'adapter (It Is Necessary to Adapt), has shown how, at the beginning of the 20th century, two prominent American thinkers, Walter Lippmann and John Dewey, offered different answers to the question of the adaptability of humans to the rapid societal change caused, then, by the industrial revolution. She writes: "For the first time in the evolution of life and living beings, one species-our human species-has found itself in a situation where it is not adapted to the new environment. For Lippmann, it was the situation where there was a huge gap between the natural inclination of the human species to remain as they were, inherited from the long and slow history of biological and societal evolution, and the need for rapid adaptability to the new environment brutally imposed by the industrial revolution. Hence the central theme of Lippmann's political studies-how to 
adapt human species to constantly and rapidly changing environment. ... The fundamental question for Lippmann was how to avoid this tension between the change and stasis, openness and closing, leading the masses to choose nationalism, fascism and generally all forms of isolationisms, in their effort to oppose the rapid change, to restore the stasis and isolation" (Stiegler, 2019, p.14).

So, it was this abyss between slow historical, biological and psychological evolution of human species and the rapidly changing physical and social environment, caused by the industrial revolution, that worried Walter Lippmann. If at the turn of the 20th century it was the industrial revolution, also combined with economic globalization, at the turn of the 21 st century it is the revolution in information technology and whipped-up globalization of economic and financial markets that have, once again, uprooted masses of people in different countries, where only those who are easily adaptable to the change can prosper. This is like a bio-social experiment of the survival of the fittest, and the fittest are the rationally thinking experts and managers as well as impartial judges using rational laws, who know in which direction humankind must and will evolve. The masses should be taught to suppress their irrational impulses and follow the lead of enlightened experts, who have been able to adapt and readapt to the constantly changing environment. In such a situation, one of the main aims of public education and mass media should be 'the manufacture of the consent' of the masses with the policies defined by experts (of which Lippmann was an expert). As to the role of politicians, Lippmann writes, that "though he [the statesman] cannot keep the life of the nation as a whole in his mind, he can at least make sure that he is taking counsel with those who know...." (Lippmann, 2013, p.98). A politician has to be only an expert in the choice of experts. While Lippmann, and all the neoliberals after him, saw the solution to the gap between rapidly changing environment and the inability of the masses to adapt to the new environment, in the combination of expertise of specialists and the "manufacturing of the consent of masses" (that is, brainwashing through the systems of education and mass media), John Dewey would rely more on the collective 
intelligence of masses. Dewey was also the first detractor of neoliberal thinking. He warned: "A class of experts is inevitably cut off from the common interests to such an extent that it becomes a class with its own private interests. Every governance by experts where masses are unable to inform the experts of their needs cannot be anything else than an oligarchy that rules in the interest of some. And enlightened information has to force the specialists to take account of the needs of masses. The world has suffered more from leaders and authorities than from masses" (Dewey, 1984, pp.364-365).

We see that this almost a century-old intellectual confrontation that has influenced policies of Western governments, where Lippmann's ideas prevailed over those of Dewey, has acquired a new acuteness with globalization and the IT revolution. It is, once again, a conflict between elites and masses, between self-proclaimed progressivists and those who are denigrated as populists or their supporters.

\section{"SEDENTARIES" vs "NOMADS"}

In his book, The Road to Somewhere, British author David Goodhart distinguishes between those whom he calls 'Anywheres' and those who according to him are "Somewheres" (Goodhart, 2017). If the members of the first category (no more than 20-25 percent of the population in the West and much less in the Rest) belong to the cosmopolitan elite that has profited from globalization and feels at home in different places in the world, the majority (more than 50 percent in the West) feels a need to maintain solid links to their country, to its history, traditions, and language. It is a conflict between those who care for their "rootedness" or entrenchment in a definitive place, be it a local village, a town or a nation-state, and cosmopolitans, i.e. those who feel at home in different places. There have always been a minority of those who see the whole world, or Europe, as the case may be, as their home, and a majority of those who feel at home only there where they were born, among those who speak the same language, profess the same religion or have similar life-styles. For centuries, the first category was a relatively small minority, while most of the people were born, lived and died in the same place, except for mass movements of population 
that have several times occurred in the history of humankind, and one of which may well be underway today.

Tensions between solidarity and diversity, between the welfare state and mass immigration have increased the divide between the 'people from anywhere' and 'people of somewhere' or as Alexander Devecchio of Le Figaro puts it, between "sedentaries" and "nomads" (Devecchio, 2019 , p.1798). Globalization and the current migration tide, as one of its manifestations, are exacerbating today's crisis in the European Union, where those who can be anywhere do not understand those who want to be somewhere. Those who can be anywhere, being dominant in politics, economy and media, are behaving like liberal autocrats vis-à-vis those whom they consider belonging to the mob. Such myopic arrogance carries a heavy social and political price-tag. Without resolving this contradiction between the aspiration of European peoples to be somewhere (to feel at home in France, in Germany, in Italy, in Estonia, in Hungary) and the ambition of transnational elites to be anywhere, Europe will not come out unscathed from the current crisis.

Populists are accused of dividing societies with their criticism of democratically elected governments and by-passing traditional media. But this is confusing the cause and the effect. The rise of populism is a symptom of a pre-existing malaise, not its cause. The populist parties and leaders have become prominent namely because Western societies have become more and more unequal and divided. While liberal ideas are prevalent among European elites, values of democracy are today often expressed by populist parties and movements. French philosopher Chantal Delsol is right when she writes that "[T]he populists, contrary to what some may say, are really democrats, but they are not liberals. At the same time, universalist elites, like those in Brussels, are really liberals, who are not any more democrats since they don't like when people vote to limit some liberties" (Delsol, 2018). Equally right was David Goodhart when he said in his interview to Le Figaro Vox that the Brexit mess was not necessarily a sign of the end of democracy, but a conflict between two visions of democracyrepresentative and direct democracy expressed, inter alia, through referenda (Goodhart, 2019). Both of them have their advantages as 
well as serious shortcomings. If representative democracy has led to the alienation of elites from the people, direct democracy may contain seeds of authoritarianism. However, the Brexit has been a mess not because of the use of a referendum as an element of direct democracy, but because of the deep divisions in society and alienation of elites from the majority of the people.

Populist parties or movements may face setbacks coming in elections and their popularity ratings may suffer. However, the phenomenon is not going away, as its causes persist. Moreover, socalled mainstream parties are more and more borrowing populist slogans and policies. The clearest example of this tendency is the metamorphoses of the British Tories, who under Boris Johnson are not any more a traditional conservative party it used to be. Having employed some traditional Labour Party precepts as well as Nigel Farage's Brexit Party ideas and luring voters from both of them, the Tories have become a populist party-partly left-wing, partly rightwing. In a way and simplifying a bit, both the Brexit and Trump's victory have been triumphs of populism over elitism (or if you like, democracy over liberalism).

\section{NEW CHALLENGES TO THE MAINSTREAM WESTERN NARRATIVE}

The invention and the spread of the Internet, worldwide web and the assent of social media, which were all meant to undermine authoritarian regimes, soon turned against liberal elites that had had dominant positions in the so-called traditional media-radio, TV, mainstream newspapers, and journals. Traditional media have been considered, already for some time and with certain justification, to be the "fourth power" of the State, together with legislative, executive, and judicial powers, though somewhat independent, but nevertheless in the service of the economic, political, and intellectual elites, similarly to the other three powers.

Those masses that had not reaped benefits of globalization and were left behind, found in social media that was not controlled by liberal elites an outlet through which to reveal their grievances and to mobilize. Their cause was picked up by those who became known 
as populist leaders, such as Donald Trump, Boris Johnson, Marine Le Pen or Matteo Salvini. Probably, these two phenomena-the globalization of economy, and particularly financial markets, and the rise of information technology-are the two sides of the same coin, contributing to the crisis of liberal democracy and turning against their progenitors. Alexander Devecchio compares the effect from the spread of the Internet to that of the invention of the printing press by Gutenberg in 1454. The latter undermined the power and position of the Roman Church and the clergy, which had controlled the peoples' minds, and led to the emergence of Protestantism, as well as religious wars. Devecchio asks: "But if the invention of the Web is going to provoke a similar fracture? This time not between Catholics and Protestants, but between traditional elites, who are in the process of losing their monopoly, which they have so far had over the mass media and the spread of information, and a new so-called elite that can convey their message bypassing the traditional channels of communication" (Devecchio, 2019, p.1581). Yascha Mounk has also observed that the social media networks have closed the gap between the people and the elites, between those who have the power and those who do not (Mounk, 2018).

The fact that the Western mainstream media are losing their "monopoly of the truth" is reflected not only in the concern of Western political and intellectual elites about the spread of social media. While during the Cold War period, it was mainly the Soviet Union that tried to shield its population from the "harmful influence of Western propaganda," today it is the West that does its utmost to limit information flows coming from the East. Forcing to close down Sputnik, for example, in Estonia, like other forms of the fight against "Russian propaganda," are all attacks on the freedom of information. I was not only saddened, but even somewhat amused, when reading about the need to restrict or counter, for example, Russian propaganda channels. No doubt, there is Russian propaganda, but only a very gullible person could have written, in the article pretentiously entitled Propaganda vs. Information Policy, that "whereas Russia has propaganda, the EU has an information policy," 
and "unlike Western media organizations, RT is not concerned with the truth" (Reichardt, 2015).

As to the Western "information policy," besides the influential views of above mentioned Walter Lippmann, it was Edward Louis James Bernays, one of the pioneers of the American propaganda machine, who considered that manipulation of public opinion was a necessary part of democracy (though later he preferred to use the term 'public relations' instead of the word 'propaganda', becoming therefore known as "the father of public relations"). In his book of 1928, Propaganda, Bernays wrote: "The conscious and intelligent manipulation of the organized habits and opinions of the masses is an important element in democratic society. Those who manipulate this unseen mechanism of society constitute an invisible government which is the true ruling power of our country [...] We are governed, our minds are molded, our tastes formed, our ideas suggested, largely by men we have never heard of. This is a logical result of the way in which our democratic society is organized. Vast numbers of human beings must cooperate in this manner if they are to live together as a smoothly functioning society [...] In almost every act of our daily lives, whether in the sphere of politics or business, in our social conduct or our ethical thinking, we are dominated by the relatively small number of persons... who understand the mental processes and social patterns of the masses. It is they who pull the wires which control the public mind" (Bernays, 1928, pp.9-10).

Today, the West has the reason to worry not because the Russian, or any other non-Western, propaganda machine is more powerful or widespread than the Western one. Since the times of Edward Bernays, the Western "public relations" policies have exponentially increased not only in power, but also in sophistication. And to such an extent that most people may sincerely believe that what they see, hear or read in their favorite channels or papers is the truth and nothing but the truth. However, there is a chasm between the dominant Western ideological narrative and global realities, or as Leonard Cohen sang, "There is a crack in everything. That's how the light gets in." And though through such cracks come in not only unadulterated truth, but also so-called 
"fake news" and a lot of rubbish, closing them would be not only impossible, but attempts to do that would destroy what the Western civilization has been rightly proud of-the freedom of information.

Of course, there are media outlets with different degrees of impartiality, and some may be more reliable than others, but more often than not their impartiality is in the eye of the beholder and most people consider as objective and impartial those media outlets whose message corresponds to their views, which, in turn, have been formed by these very outlets.

\section{SYMPATHIZING WITH POPULIST ELECTORATE, BUT OPPOSING THOSE ELECTED}

Our ideas and approaches are more dictated by our personal histories than by what may be called "objective" reality. I have become, through hazards and ambition, someone whose profession and lifestyle are, par excellence, cosmopolitan. Having held professorships in most prestigious universities, and worked at various diplomatic posts, I probably also belong to a kind of cosmopolitan intellectual elite. However, maybe because I was brought up by a single mom and my grandparents in a remote Estonian village and having dropped out of school at the age of 15, starting making my own living, I feel strong affinity with many of those who vote for populist parties. I would even say that while I feel sympathy for the populist electorate, I have usually much less respect for those whom this electorate brings to power.

Personally, I am not comfortable with Boris Johnson's rude manners and I find that he has too often, even for a politician, been economical with the truth. As an Estonian national living in London with my family, who are all Estonian passport holders, I am personally uncomfortable with the Brexit too. Yet this does not mean that I cannot see genuine concerns of Brexiteers, although such a situation when personal interests and academic analysis do not overlap is relatively rare. I would like to illustrate this point by my recent experience. In September 2019 I took a minicab from my home in Blackheath of South-East London to Heathrow in the North West of the city to catch a flight to Xi'an, in the Chinese heartland, where I stayed until the 
coronavirus hit Wuhan. The driver told me that in 2016 he had voted for the Brexit. He also emphasized that if Britain would fail to exit from the European Union, he would never participate in future elections, since this would be one more sign that the voice of the people does not matter. I did not argue with him, since there I was-a non-Brit, though having lived for long in London, being obviously one of those who feels at home, if not everywhere, then at least in many places, including London, and here he was-a Brit, who had been born and had lived his whole life in Kidbrooke in South London, being one of those who wanted to live there where they were born and brought up. This was an encounter of typical "anywhere" with a typical "somewhere." He told me that he had traveled quite a lot, though his trips had been quite different from my numerous journeys. For example, in the summer of 2018, he had been to Russia to support the English national team in its World Cup efforts and he was looking forward to his next flight to Japan to support the English rugby team. And almost during our entire trip from Blackheath to Heathrow, he attentively listened to the radio transmission of the cricket match between England and Australia that was going at the Oval Stadium, which we were passing on our way, while for me the world without the cricket would not make any difference. Our chance encounter that lasted less than two hours revealed to me, at a very personal level, the conflict of interests and perceptions that was happening at the level of the country, and even beyond.

However, notwithstanding our differences, I am still able to understand this Brexiteer minicab driver. I also understand my relatives in Southern Estonia, who voted for EKRE-the party whose leaders are, to put it mildly, very unsympathetic for me. However, I agree with Canadian essayist Mathieu Bock-Coté who writes that "there are, no doubt, among populist politicians extreme rights who nurture crazy and repulsive ideas, but it would be wrong to confuse ideological obsessions of such politicians and those real issues that form the basis of a significant part of the electorate and public concerns that have been censured by the dominant ideology" (Bock-Coté, 2019, pp.291292). These are the faults of so-called mainstream political parties, be 
they center-right or center-left, which have neglected these real issues. Populist leaders, like anybody else, can exploit only what is exploitable.

\section{NATION-STATES AS CRADLES OF DEMOCRACY AND SUBJECTS OF INTERNATIONAL LAW}

Contemporary democracy, i.e. government by the people and for the people, emerged and evolved within nation-states and seems to be inseparable from it. Yet economic liberalism with global uncontrolled financial markets, together with social liberalism, putting the primacy of the individual with his interests and desires above the interests of society, are destroying social bonds that have helped hold societies together. As a result, they are also undermining nation-states-the cradles of democracy. Supporting and promoting diversity within societies lead, as a corollary, to the elimination of diversity between societies organized as states. Some societies, especially in the West, have become so diverse that the societal bonds holding them together are at the breaking point. In others, particularly in the East and the South, attempts to implant societal models borrowed from the West, instead of taking root in the hostile soil, are destroying traditional institutions and creating failed states.

Benedict Anderson was not completely wrong when he defined nations as "imagined communities" (Anderson, 1983), since historical myths and purposeful efforts of political leaders to make a nation out of diverse communities have often played a role in nation-building. As Italian novelist and politician Massimo Taparelli d'Azeglio put it in 1861, "We have created Italy. Now all we have to do is to create Italians" (Tharoor, 1998, p.128). However, there is also something much more tangible, even primordial, without which nations would not and could not emerge. Shared history, cultural and religious traditions, common language, territorial closeness, battles won or lost are all factors that have played a necessary role in the formation of nations.

Nationalism, the formation of nation-states and the development of democracy in Europe went hand in hand. Without nationalism there would not have been nation-states, without nation-states there would not have been democracy, at least in its current form. John Stewart Mill, 
summarizing the practices of democratic institutions in the middle of the 19th century, wrote that it was "a necessary condition of free institutions that the boundaries of government should coincide in the main with those of nationalities" and that "among a people without fellow-feeling, especially if they read and speak different languages, the united public opinion necessary to the workings of representative institutions cannot exist" (Mill, 1993, pp.392-394). A century later, British diplomat and theorist of international relations Adam Watson concluded that "the self-assertion of the middle class in Europe took two forms: the demand for participation in government, and nationalism" and that "the ideas of nationalism and democracy were related" (Watson, 1992, pp.230, 244). However, more than two centuries after Mill and contrary to him, Daniel Cohn-Bendit, the 1968 students' movement leader, reflecting on the continuing effect of those events, opined that 1968 had opened the way to the diversity paradigm (paradigme diversitaire). He wrote: "For me, this was the opening of thoughts to the acceptance of differences as a unifying factor. The recognition of differences may unite us and give additional strength to the society" (Cohn-Bendit, 2008). Certainly, today's European societies have radically changed in comparison with the times of John Stewart Mill; they have become much more diverse and the acceptance of such diversity has also increased. However, there are also differences that make the integration of a society impossible, leading to the parallel existence of antagonistic sub-cultures within one and the same society that, at the end of the day, loses its societal characteristics. Today, many decades on, more and more Europeans, being afraid of becoming strangers at home, in their own country, city or even village, are in search of their roots. And these are not only those losers in the hyper-globalized world, who care about where and with whom they live. Many highly intelligent, successful and multi-lingual persons treasure their ethnic, religious or cultural origins, are patriots of their countries and cherish their roots.

Today, we see that due to the increasing heterogeneity of most societies, these two phenomena-nationalism and democracy-like liberalism and democracy, are showing more negative than positive aspects of their controversial relationship.Or are they all negative? 
Often this depends on whose point of view you prefer. Is Catalonian nationalism that demands independence for Catalonia from Spain negative or positive? Or whose nationalism would be preferable: the English, which has led to the withdrawal of the (still) United Kingdom from the European Union, or Scottish nationalism that, failing in 2014 to separate Scotland from the United Kingdom, is now, after the Brexit, attempting to leave Britain in order to remain in the EU? A more general and important question, to which I do not have a definitive answer, is whether democracy can at all exist without stable nation-states? To say the least, I have serious doubts about such possibility.

In that respect a disturbing, in my opinion, but optimistic from the point of view of the authors, scenario was depicted in the joint article by Anne Hidalgo, the mayor of Paris, and Sadiq Khan, the mayor of London, published in Le Parisien and The Financial Times. Complaining about the lethargy of nation-states (in that respect they were right), they predicted the emergence in the 21 st century of a world of cities, instead of the 19th century world of empires and the 20th century world of nation-states (Khan and Hidalgo, 2016). These would be London, Paris, New York, Tokyo and other conglomerates that would lead the world instead of nations organized as states. Although it is often said, and that is true, that, for instance, Moscow is not Russia, New York is not America, and Paris is not France, further concentration of elites in big cities while neglecting the periphery, is a sure way to further divide the nations. Besides, big cities face no less acute problems and difficulties than nation-states, which have started waking up from their lethargy.

Even more utopian is the idea of a world government, which would be liberal imperialism under the name of liberal international order, an equally utopian concept. In international relations the closest to the notion of democracy is a system of balance of power, in which the claims of one power to dominance or hegemony would be countered by another power or other powers. This was well understood already by famous Swiss international lawyer Emerich de Vattel, who in 1758 in his The Law of Nations wrote about the foundation of international 
law: "This is the famous idea of the political balance or equilibrium of power. We have in mind a situation where no power is able to dominate absolutely, to make laws for others" (Vattel, n.d., $\$ \$ 47-48$ ). Lassa Oppenheim wrote in the first edition of his famous treatise on international law: "Law of Nations can exist only if there is equilibrium, a balance of power, between the members of the Family of Nations" (Oppenheim, 1905, p.73). In that respect the world has not changed. Even today the arrogance of one superpower can be controlled by the might of another superpower (or a coalition of powers); international law can be helpful and play its role in this process, but without such a balance it not only becomes helpless, but it simply disappears, paving way for the emergence of imperial law.

\section{A CRITIC OF LIBERAL IMPERIALISM}

In parallel with the growth of "undemocratic liberalism," there rose its counterpart in international relations_- "liberal imperialism," euphemistically called "liberal international order." Liberal imperialism, i.e. attempts to impose liberal values, either by persuasion or by force, as universal values upon all and everyone, is a wake-up call for those for whom, say, collectivistic values, historical traditions, stability or national independence are more, or at least not less, important than individual liberties. Many influential liberal authors, be they philosophers or economists, have been campaigners for a liberal imperial order. Friedrich Hayek, one of the most important theoreticians of liberalism of the last century, believed that the idea of interstate federation would be "the consistent development of the liberal point of view" (Hayek, 2017), while Ludwig von Mises advocated the end of nation-states and creation of a "world super-state" (Mises, 1985, p.150). Israeli author Yoram Hazony, in his book with a somewhat provocative title, The Virtue of Nationalism, is right when asserting that: "For all their bickering, proponents of the liberal construction are united in endorsing a single imperialist vision: They wish to see a world in which liberal principles are codified as universal law and imposed on the nations, if necessary by force. This, they agree, is what will bring us universal peace and prosperity" (Hazony, 2018, p.45). 
In the 1990s, in the context of the triumphant Fukuyamian liberalism, many influential authors prophesized the demise of nation-states that have been the main and indispensable subjects of international law. For example, Japanese economist, businessman and public intellectual Kenichi Ohmae and Frenchman Jean-Marie Guehenno, former UN Under-Secretary General for Peace-Keeping Operations, both published books with almost identical titles The End of the Nation-State (Ohmae, 1995; Guehenno, 2000). Yoram Hazony writes that his "liberal friends and colleagues do not seem to understand that the advancing liberal construction is a form of imperialism" (Hazony, 2018, 43) and that "the emerging liberal construction is incapable of respecting, much less celebrating, the deviation of nations seeking to assert a right to their own unique laws, traditions, and policies. Any such dissent is held to be vulgar and ignorant, if not evidence of a fascistic mindset" (Hazony, 2018, p.49). He observes that with the fall of the Berlin Wall in 1989, "the Western minds became preoccupied with two great imperialist projects: the European Union, which has progressively relieved member nations of many of the powers usually associated with political independence; and the project of establishing an American 'world order', in which nations that do not abide by international law will be coerced into doing so, principally by means of American military might. These are imperialist projects, even though their proponents do not like to call them like that" (Hazony, 2018, pp.3-4).

In defense of international law it should be said that it is not this rather noble normative system, which willy-nilly worked even during the Cold War (to a great extent, due to the existing balance of power), that Washington tries to impose by its military might or by sanctioning those who disobey, but the so-called "'rules-based liberal international order," i.e. the order based on rules determined in Washington that have little to do with international law. And it is not accidental that the only aspiring global empire is accusing those opposing its imperial ambitions, especially China and Russia, of either building or restoring their own empires.

It is unfair, in my opinion, to accuse the European Union of being an imperial project, though one may agree that while promising (and 
acting on this promise) to create an "ever-closer union," a kind of federal Europe, European political elites have gradually become more and more detached from the aspirations of their peoples. It is becoming increasingly obvious that European societies, in contradistinction to political elites, are not ready to throw the nation-state into the dustbin of history. However, the European Union may still increase its strategic autonomy, especially vis-à-vis Washington and Beijing. This can be done by considerably improving relations with Moscow. If Washington, in an attempt to perpetuate its global domination, may be interested in the simultaneous containment of both China and Russia (although this is a dangerous and probably even counterproductive endeavor), Europe is suffering from its poor relations with Moscow no less than Russia is. There is no benefit whatsoever for Europe in demonizing Russia and its political leadership. Having at least a normal relationship with Russia would not only be economically beneficial for Europe; it would also widen the space of strategic maneuvering for Europe even without creating a European super-state. As French political scientist Caroline Galactéros (2019) incisively puts it, "strategic rapprochement of the EU with Russia would add additional value to Europe in new geopolitical games."

This has been my diagnosis of the problems without proposing, so far, any solutions. It is particularly difficult to find solutions due to the confrontational approaches prevailing in today's politics: it is either we or they. In the domain of geopolitics, it is the West versus China and Russia, with liberals denigrating populists within Western societies (populism is spreading across Europe "like leprosy," to use President Macron's term). Compromises are seen as signs of weakness both within and between states. However, while radicalism may be good in sports or arts, it is dangerous in politics. Moreover, in these matters there is no absolute truth in practical, not only in philosophical, terms. French philosopher Luc Ferry has put it well in the context of some current bloody conflicts: "The truth, in contrast to what the majority of small-scale moralists think, is that many bloody conflicts in today's world are tragic in the sense of Greek tragedies where the opposing 
sides represent not the good and the evil, right and wrong, but quite legitimate, though differing, claims. Had I been a Western Ukrainian of Polish origin, I would have probably wanted my country to join the European Union and even NATO. However, had I been from East Ukraine, from a Russian-speaking family, I would almost certainly have wanted my country to be closely attached to Russia. Had I been a Palestinian boy of fifteen from the occupied territories, I would without doubt be an anti-Semite; by contrast, an Israeli of the same age from Tel-Aviv I would almost certainly despise Palestinian organizations" (Ferry, 2016, p.222).

Although among the world's rich palette of ideologies, practices and trends there are also those who represent what may be defined as absolute evil and deservedly call for moral outrage, most often in today's conflicts either between or within nations one can rarely come across a situation where one camp is absolutely right while the other side is absolutely wrong.

In geopolitics it would be advisable to aim towards the system of balance of powers, modeled after the 1815 Congress of Vienna, but able to tackle the challenges of the 21st century. In liberal democracies, both progressist and populists, toning down their reciprocal accusations, should start healing the divisions that have become unacceptable in most societies. Until those who can be anywhere will not understand and recognize the problems of those who prefer to be somewhere, and vice versa, we will be moving towards a tipping point (or a point of no-return) where a revolutionary situation may end up in a revolution or a war.

\section{References}

Anderson, B., 1983. Imagined Communities: Reflections on the Origin and Spread of Nationalism. Verso.

Bernays, E.L., 1928. Propaganda. Routledge.

Bock-Coté M., 2019. Le Multiculturalisme comme Religion Politique [Multiculturism as a Political Religion]. Cerf.

Galactéros, C., 2019. Un nouveau partage du monde est en train de se structurer [A New Division of the World]. Figaro Vox, 9 November. 
Cohn-Bendit, D., 2008. Forget 68. Éditions de l'aube.

Dahrendorf, R., 2003. Acht Anmerkungen zum Populismus [Eight Notes on Populism]. 156 Transit-Europäische Revue, 25.

Delsol, C., 2018. Populiste, c'est un adjectif pour injurier ses adversaires ['Populist' as an Adjective to Hurt Your Adversaries]. Le Figaro Vox, 6 September.

Devecchio, A., 2019. Recomposition: Le nouveau monde populiste [Reconstruction: A New Populist World]. Serf.

Dewey, J., 1984. The Public and Its Problems in The Later Works of John Dewey 1925-1953, Vol. 2. Southern Illinois University Press.

Ferry L., 2016. La Révolution Transhumaniste: comment la technomédecine et l'uberisation du monde boulverser nos vies [The Transhumanist Revolution: How Techno-Medicine and the Uberization of the World Destroy Our Lives]. Plon.

Goodhart, D., 2017. The Road to Somewhere: The New Tribes Shaping British Politics. Penguin.

Goodhart, D., 2019. Après le Brexit, le Royaume-Uni ne va pas couler en mer [After Brexit: The UK Will Not Sink]. Le Figaro Vox, 4 October.

Guehenno, Jean-Marie, 2000. The End of the Nation-State. University of Minnesota Press.

Hayek, F., 2017. The Economic Conditions of Interstate Federalism [online]. 17 April. Available at: <https://fee.org/articles/the-economic-conditions-ofinterstate-federalism $>$ [Accessed 04 February 2020].

Hazony, Y., 2018. The Virtue of Nationalism. Basic Books, p.45.

Khan, S. and Hidalgo, A., 2016. London and Paris Are Leading the Charge to Shape the 21st Century. The Financial Times, 27 June.

Lippmann, W., 2013. A Preface to Politics. HardPress Publishing.

Mill, J.S., 1993. Utilitarianism. On Liberty: Considerations of Representative Government. Basil and Blackwell.

Mises, L. von, 1985. Liberalism in the Classical Tradition. Cobden Press.

Mounk, Y., 2018. The People vs. Democracy: Why Our Freedom Is in Danger and How to Save It. Harvard University Press.

Ohmae, Kenichi, 1995. The End of the Nation State: How Regional Economics Will Soon Reshape the World. Simon \& Schuster. 
Oppenheim, L.F.L., 1905. International Law: A Treatise. Vol. I, Peace. London.

Reichardt, A., 2015. Propaganda vs. Information Policy. New Eastern Europe, 27 April.

Rorty, R., 1997. Achieving Our Country. Harvard University Press.

Stiegler, B., 2019. Il faut sadapter: sur un nouvel impératif politique [It Is Necessary to Adapt: On a New Political Imperative]. Gallimard.

Tharoor, S., 1998. E Pluribus, India: Is Indian Modernity Working? Foreign Affairs, 77(1).

Vattel, Emerich de, n.d. Le Droits des Gens [The Law of Nations], Chapter III, $\$ \$ 47-48$.

Watson, A., 1992. The Evolution of International Society. Routledge.

Zakaria, Fareed, 1997. The Rise of Illiberal Democracy. Foreign Affairs, 76 (6) November/December, pp.22-43. 